\title{
TEXT AND TALK AS SOCIAL PRACTICE
}




\section{CONTEXT: \\ Sociological Studies on Text, Discourse and Conversation}

The CONTEXT Series is designed to bring into focus sociological studies on text, conversation and discourse. Each volume in the series will explore why and how various approaches to text, discourse or conversation analysis can contribute empirically or theoretically to the understanding of contemporary issues in the social sciences.

\section{Editors}

Joke Haafkens, Institute for Psychiatry, Erasmus University Rotterdam

Tony Hak, Department of Sociology, Erasmus University Rotterdam

Gerhard Nijhof, Department of Sociology, University of Amsterdam

Brian Torode, Department of Sociology, Trinity College Dublin

Other books in this series:

Kathy Davis, Power under the Microscope 
Brian Torode (ed.)

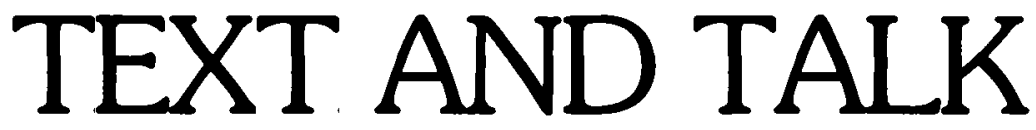

AS SOCIAL

PRACTICE

Discourse difference and division in speech and writing

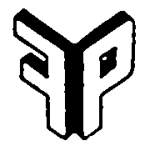

1989

FORIS PUBLICATIONS

Dordrecht - Holland/Providence RI - U.S.A. 
Published by:

Foris Publications Holland

P.O. Box 509

3300 AM Dordrecht, The Netherlands

Distributor for the U.S.A. and Canada:

Foris Publications USA, Inc.

P.O. Box 5904

Providence Rl 02903

U.S.A.

\section{CIP-DATA KONINKLIJKE BIBLIOTHEEK, DEN HAAG}

Text

Text and Talk as Social Practice : Discourse Difference and Division in Speech and Writing /

Brian Torode, ed. - Dordrecht [etc.] : Foris. - (Context ; 2)

With bibliogr., index.

ISBN 90-6765-411-6

SISO 803.2 UDC $800.852+800.855$

Subject heading: Sociolinguistics.

ISBN 9067654116

(ㄱ) 1989 Context

No part of this publication may be reproduced or transmitted in any form or by any means, electronic or mechanical, including photocopy, recording, or any information storage and retrieval system, without permission from the copyright owner.

Printed in The Netherlands by ICG Printing, Dordrecht. 